\title{
Characteristics of Growth, Pigment and Monacolin K Production by Monascus strains in Liquid Culture
}

\author{
Jin-Won Seo ${ }^{1+}$, Chang Sup Kim ${ }^{2+}$, Eun Jeong Seo ${ }^{1}$, Che Ok Jeon ${ }^{3}$, Hyung-Kyoon Choi ${ }^{4}$, and Youn-Je Park ${ }^{1}$ *
}

접수: 2012년 10월 3일 / 게재승인: 2012년 10월 26일

(C) 2012 The Korean Society for Biotechnology and Bioengineering

\begin{abstract}
The hyphal growth, production of color pigments and monacolin $\mathrm{K}$ by Monascus strains were investigated in liquid medium. Thirty five different strains were collected and cultured in potato dextrose yeast extract broth (PDYB), potato dextrose broth (PDB) and malt extract broth (MEB) medea at $25^{\circ} \mathrm{C}$ for 7 days. The growth rates of most of strains were highest in PDYB medium. Growth rate as well as pigment production were influenced by suspension conditions of mycelia during liquid cultivation. Most of strains producing monacolin $\mathrm{K}$ corresponded to strains producing red pigment highly and showing more $\mathrm{pH}$ changes of liquid media. Monacolin K produced from strains was detected in culture broth as well as mycelia. Any citrinin was not detected in monacolin $\mathrm{K}$ producing strains. These results imply that the selection of the strains producing red pigment highly and

\footnotetext{
${ }^{1}$ 차의과학대학교 바이오공학과

${ }^{1}$ Department of Applied Bioscience, CHA University, Seongnam, Gyeonggi-do, 463-840, Korea

Tel: +82-31-8017-9464, Fax: +82-31-8017-9464

e-mail: yjpark@cha.ac.kr

${ }^{2}$ 한밭대학교 화학생명공학과

2Department of Chemical and Biological Engineering, Hanbat National University, Daejeon 305-719, Korea

${ }^{3}$ 중앙대학교 생명과학과

${ }^{3}$ Department of Life Science, Chung-Ang University, Seoul, 156-756, Korea

4 중앙대학교 약학대학

${ }^{4}$ College of Pharmacy, Chung-Ang University, Seoul, 156-756, Korea

$\dagger$ 제 1 공동저자

${ }^{\dagger}$ These authors contributed equally to this work.
}

showing more $\mathrm{pH}$ changes in liquid cultivation could be applied for primary screening of Monascus strains for preparation of red mold rice.

Keywords: Monascus, liquid culture, growth rate, monacolin K, pigment

\section{1. 서론}

홍국균 (紅麴菌)은 Monascus 속 균류가 쌀이나 콩에 발효하 여 생성된 선홍색 누룩으로서, 1884년 van Tieghem에 의해 감자에서 처음 분리되었고 [1], 쌀에서는 1895 년 Went에 의 해 처음 분리되었다 [2]. 이후 다양한 종류의 균주가 쌀 등의 자연계로부터 분리되어 동정되었고, Hawkworth 등은 동양 의 전통 식품으로부터 분리된 Monascus 균주를 M. purpureus, M. ruber, M. pilosus 등 3 개의 종으로 재분류한 바 있다 [3]. 이 균은 분류학적으로 자낭을 만드는 자낭균류에 속하며, Ascomycotina 문, Plectomycetes 강, Eurotiales 목, Monascaceae 과, Monascus 속 (홍국균속)으로 분류되고 있다. 또한, 적색계통의 색소를 많이 생산하는 특징을 가지고 있어 발효물이 적색이나 심홍색을 나타내게 되는데, 이러한 이유 때문에 Monascus 속을 홍국균으로 부르고 있다.

홍국균이 쌀 등의 곡류에 발효된 홍국 (紅麴)은 중국, 일 본, 대만 등 동아시아 지역에서 오래전부터 전통적으로 사용 되어 왔으며, 중국의 본초강목에는 소식활혈 (消食活血)이나 건비조위 (健脾燥胃)의 기능이 기록되어 있고, 한국의 동의 보감에도 홍국은 피를 잘 돌게 하고 음식이 소화되게 하며 이질을 멎게 하는 신국 (神麥匊)이라고 기록되어 있다 [4]. 그 
외에도 홍국은 오래전부터 착색, 양조, 방부 등의 기능으로 사용되어 왔고, 식품과 한약재의 원료로 사용되어 왔다.

홍국의 이러한 기능은 홍국균이 생산하는 이차대사산물 에 의해 나타나는 것으로, 주된 기능성분은 monacolin $\mathrm{K}$ 이 다 [5]. 홍국균으로부터 생산되는 monacolin $\mathrm{K}$ 의 기능성은 1979년 일본의 Endo 교수에 의해 처음 밝혀졌으며 [6], 이 물질은 cholesterol 합성에 관여하는 효소인 HMG-CoA (3Hudroxy-3-Methyl Glutaryl CoA) reductase의 활성을 저해 하여 혈중 콜레스테롤 수치를 저하시키는 기능을 하는 것으 로 알려져 있다 [7]. 이후 여러 가지 생리활성 기능에 대한 연구가 진행되었고, 특히 monacolin $\mathrm{K}$ 성분에 의한 고지혈 예방 및 치료기능을 갖는 건강기능식품으로 개발되기 시작 하였다. 최근에는 홍국에 의한 항암 [8], 항산화 [9], 항염효 과 [10] 등이 밝혀지고 있으며, 구미에서는 이를 이용하여 홍 국을 분쇄한 분말이나 추출물 제품을 개발하여 판매하고 있다.

홍국균은 monacolin $\mathrm{K}$ 외에도 다양한 색소를 많이 생산하 고 있는데, 홍국의 색소성분은 주로 적색과 황색 계통의 색소 로서, monascin, ankaflavin, rubropunctatin, monascorubrin 등으로 구성되어 있다 [11]. 홍국의 색소는 온도와 $\mathrm{pH}$ 에 안 정하고, 단백질, 펩타이드 등에 친화성이 강하여 점착성이 큰 성질을 가지고 있고 주로 착색제로 많이 이용되고 있다 [12]. 이들 색소 성분 역시 항암 효과, 항균 효과 등 다양한 생리적 기능도 함께 나타내어 최근에는 홍국이 생산하는 색소의 중요 성도 커지고 있다 $[13,14]$. 이들 색소의 생산은 사용균주와 영양성분, 및 배양조건에 따라 색소의 종류와 구성성분이 달라지는 것으로 알려져 있다 [15].

홍국균이 생산하는 주요 성분인 monacolin $\mathrm{K}$ 는 균체내에 서 생합성되는 물질로서 polyketide pathway를 거쳐 acetate 와 methionin이 결합하여 생성되는 화합물이다 [16]. 또한, 홍국이 생산하는 여러 색소들과 신독소로 작용하는 citrinin 등의 이차대사산물들도 동일한 합성경로를 거치는 것으로 알려져 있다 [17]. 따라서, 홍국을 고체발효하여 제조하는 홍국쌀에는 유용성분인 monacolin $\mathrm{K}$ 와 여러 색소, 그리고 citrinin이 함께 함유되어 있는 경우가 많으며 [18], 이러한 성분의 함량은 균주의 종류와 배양조건에 의해 결정된다.

홍국균을 이용하여 홍국쌀을 제조하기 위해서는 홍국쌀 제조에 적합한 균주의 선정이 필요한데, 균주의 선정은 주로 홍국균을 쌀에 접종한 후 배양하여 생산하는 monacolin $\mathrm{K}$ 의 함량이나 색소성분의 생산량, 그리고 독소성분으로 알려 진 citrinin의 함량을 기준으로 진행한다. 일반적으로 독소 로 작용하는 citrinin의 생산량은 적고 monacolin $\mathrm{K}$ 와 적색 색소의 생산량이 높은 균주를 선발하는 것이 중요하다. 그 러나, 홍국균을 쌀에 접종한 후 고체발효를 통하여 균주를 선발할 경우 시간이 오래 걸리고, 많은 균주들을 한꺼번에 실험하기가 어려운 단점이 있다. 이에 비해 액체배양을 통해 균주를 배양하면 비교적 짧은 시간 내에 결과를 얻을 수 있 고 상대적으로 많은 균주를 실험할 수 있다. 따라서, 균주의 액체배양을 통하여 우선적으로 monacolin $\mathrm{K}$ 를 생산하고 적 색 색소를 많이 생산하는 균주를 미리 선발한 후 이들 균주 를 이용하면 고체발효에서 monacolin $\mathrm{K}$ 나 색소의 생산량 이 적은 균주들도 실험해야 하는 불필요한 노력을 줄일 수
있다. 또한, 홍국쌀 생산을 위한 종균은 대부분 액체배양을 통하여 증식하고 있으며, 최근에는 액체배양으로 monacolin $\mathrm{K}$ 나 색소를 생산 하고 있으므로 액체배양에서의 균주의 생 장과 물질 생산 특성을 확인할 필요가 있다.

본 연구에서는 monacolin $\mathrm{K}$ 생산에 적합한 균주를 찾기 위한 방법으로 국내에 있는 35종의 Monascus 균주를 대상 으로 액체배지에서의 균주별 배양 특성과 monacolin $\mathrm{K}$ 생산 성 및 색소 생산성을 확인하고자 하였다.

\section{2. 재료 및 방법}

\section{1. 균주 및 배지}

실험에 사용한 홍국균은 식약청에서 건강기능식품 제조에 사

Table 1. List of Monascus strains used in this study

\begin{tabular}{|c|c|c|c|}
\hline No. & Species & Strain name & $\begin{array}{l}\text { Recommended } \\
\text { condition }\end{array}$ \\
\hline 1 & Monascus ruber & КССМ 60141 & ${ }^{1)} \mathrm{PDYA}, 24^{\circ} \mathrm{C}$ \\
\hline 2 & Monascus perpureus & KCCM 11832 & ${ }^{2)} \mathrm{MEA}, 26^{\circ} \mathrm{C}$ \\
\hline 3 & Monascus perpureus & KCCM 12002 & 3) $\mathrm{PDA}, 24^{\circ} \mathrm{C}$ \\
\hline 4 & Monascus perpureus & KCCM 60170 & MEA, $30^{\circ} \mathrm{C}$ \\
\hline 5 & Monascus perpureus & КССМ 60461 & PDYA, $24^{\circ} \mathrm{C}$ \\
\hline 6 & Monascus perpureus & КССМ 60462 & PDYA, $24^{\circ} \mathrm{C}$ \\
\hline 7 & Monascus perpureus & КССМ 60016 & PDA, $24^{\circ} \mathrm{C}$ \\
\hline 8 & Monascus ruber & КСCM 60167 & $\mathrm{PDA}, 24^{\circ} \mathrm{C}$ \\
\hline 9 & Monascus pilosus & КССМ 60084 & PDYA, $24^{\circ} \mathrm{C}$ \\
\hline 10 & Monascus pilosus & КССМ 60160 & MEA, $26^{\circ} \mathrm{C}$ \\
\hline 11 & Monascus ruber & KCCM 118 & MEA, $30^{\circ} \mathrm{C}$ \\
\hline 12 & Monascus perpureus & KCCM 11 & MEA, $26^{\circ} \mathrm{C}$ \\
\hline 13 & Monascus ruber & KCCM 11876 & PDYA, $26^{\circ} \mathrm{C}$ \\
\hline 14 & Monascus perpureus & KCCM 3 & MEA, $26^{\circ} \mathrm{C}$ \\
\hline 15 & Monascus ruber & $\mathrm{KCCM}$ & PDYA, $24^{\circ} \mathrm{C}$ \\
\hline 16 & Monascus perpureus & $\mathrm{KCCM}$ & MEA, $30^{\circ} \mathrm{C}$ \\
\hline 17 & Monascus perpureus & $\mathrm{KCC}$ & MEA, $30^{\circ} \mathrm{C}$ \\
\hline 18 & Monascus pilosus & $\mathrm{KCCM}$ & MEA, $30^{\circ} \mathrm{C}$ \\
\hline 19 & Monascus pilosus & KCCM 603 & 4) $\mathrm{SDA}, 26^{\circ} \mathrm{C}$ \\
\hline 20 & Monascus pilosus & КСCM 60396 & MEA, $26^{\circ} \mathrm{C}$ \\
\hline 21 & Monascus perpureus & KCCM 601 & MEA, $24^{\circ} \mathrm{C}$ \\
\hline 22 & Monascus ruber & КССМ 60392 & PDA, $28^{\circ} \mathrm{C}$ \\
\hline 23 & Monascus ruber & $\mathrm{KC}$ & $\mathrm{SDA}, 26^{\circ} \mathrm{C}$ \\
\hline 24 & Monascus perpureus & КССМ 60397 & MEA, $26^{\circ} \mathrm{C}$ \\
\hline 25 & Monascus ruber & КССМ 60400 & SDA, $30^{\circ} \mathrm{C}$ \\
\hline 26 & Monascus ruber & КССМ 60401 & MEA, $30^{\circ} \mathrm{C}$ \\
\hline 27 & Monascus perpureus & KCT & PDA, $24^{\circ} \mathrm{C}$ \\
\hline 28 & Monascus ruber & КСТC 6122 & $\mathrm{PDA}, 24^{\circ} \mathrm{C}$ \\
\hline 29 & Monascus pilosus & KACC 46219 & PDA, $24^{\circ} \mathrm{C}$ \\
\hline 30 & Monascus purpuret & KACC 46221 & ${ }^{5)} \mathrm{CMA}$ \\
\hline 31 & Monascus purpureus & KACC 46222 & PDA \\
\hline 32 & Monascus ruber & KACC 46224 & PDA \\
\hline 33 & Monascus ruber & KACC 46225 & $\mathrm{CMA}, 24^{\circ} \mathrm{C}$ \\
\hline 34 & Monascus ruber & KACC 46226 & CMA \\
\hline 35 & Monascus pilosus & KACC 46319 & $\mathrm{PDA}, 24^{\circ} \mathrm{C}$ \\
\hline
\end{tabular}

1) PDYA: Potato dextrose yeast extract agar medium.

${ }^{2)}$ MEA: Malt extract agar medium.

${ }^{3)}$ PDA: Potato dextrose agar medium.

4) SDA: Sabouraud dextrose agar medium.

${ }^{5)}$ CMA: Corn meal agar medium. 
용할 수 있도록 인정하고 있는 균주인 M. ruber, M. perpureus M. philosus, M. anka 4종에 속하는 균주를 수집하여 사용하 였다. 수집기관은 한국미생물보존센터 $(\mathrm{KCCM})$, 생명공학 연구원 미생물지원센터 (KCTC)를 이용하였고, 해외기관인 $\mathrm{CBS}$ 에서 보관하고 있는 해외 균주들은 한국농업미생물자원 센터 (KACC)를 통하여 분양 받아 사용하였다 (Table 1).

실험에 사용한 총 균주수는 35 개 균주로 M. perpureus가 15종, M.ruber가 13종, M. pilosus가 7종이 수집 되었고 이 를 이용하여 실험에 사용하였다.

실험 균주의 사용 배지는 기본적으로 추천되고 있는 배지 인 potato dextrose yeast extract agar (PDYA, Difco, USA), potato dextrose agar (PDA, Difco, USA), malt extract agar (MEA, Difco, USA) 등을 사용하였고, 일부 균주는 Sabouraud dextrose agar (SDA, Difco, USA), corn meal agar (CMA, Difco, USA) 배지 등을 추가로 사용하였다. 각 균주는 각각 PDYA, PDA, MEA, SDA, CMA 배지에서 $25^{\circ} \mathrm{C}$ 에서 7일간 균체를 배양하여 사용하였고, 생리적 활성을 유지하기 위하 여 1 주 간격으로 계대 배양하며 실험을 진행 하였다.

액체배양에 사용한 배지는 potato dextrose yeast extract broth (PDYB, Difco, USA), potato dextrose broth (PDB, Difco, USA), malt extract broth (MEB, Difco, USA)를 사용하였다.

\section{2. 액체배지에서의 생장 특성}

액체배양에서의 균주별 생장속도를 파악하기 위하여 배지 별로 균주를 접종하고 액체배양 후 균체량을 측정하였다. 먼저 $250 \mathrm{~mL}$ 삼각플라스크에 $50 \mathrm{~mL}$ 액체배지를 넣고 멸균 한 다음 고체평판배지에서 배양한 균주를 $5 \mathrm{~mm}$ 크기의 디스크로 자른 후 각각 5 개를 액체배지에 접종하였다. 액체 배양은 진탕배양기에서 $25^{\circ} \mathrm{C}$ 에서, 7 일간 $180 \mathrm{rpm}$ 으로 교 반하며 배양하였고, 배양 후 filter paper (No. 2, Whatman, England)를 이용하여 1시간 동안 여과하여 배양액과 균체 를 분리하였다. 분리한 균체는 별도로 수득하여 균체질량 (wet cell weight)을 측정하였고, 배양액을 이용하여 배양 종료 시점의 $\mathrm{pH}$ 를 측정하였다.

\section{3. 색소 성분 분석}

액체배양 후 각 균주가 생산하는 색소량은 각 배지에서 균 주를 배양한 다음 균체를 여과하여 수득한 배양액을 이용 하였다. 각 균주의 배양액을 96 well plate에 $100 \mu \mathrm{L}$ 씩 분 주한 다음 spectrophotometer (Infinite M200Pro, TECAN, Swizzerland)를 이용하여 흡광도를 측정하였다. 균주의 색소 생산량은 황색 색소는 $385 \mathrm{~nm}$ 에서, 적색 색소는 $495 \mathrm{~nm}$ 에 서 측정한 값을 생산량으로 하였다 [19].

\subsection{Monacolin $K$ 및 citrinin 분석}

홍국균이 생산하는 주요 유용성분인 monacolin $\mathrm{K}$ 와 신장 독소로 작용하는 citrinin의 분석은 식약청에서 고시한 건강기 능식품의 기준 및 규격의 시험방법 III.3.6.6과 III.2.5.4에 따 라 표준분석방법인 HPLC 방법을 사용하여 분석하였다 [20].

Monacolin K의 분석은 HPLC (Dionex ultimate3000)를
이용하여 UV detector를 이용하여 $237 \mathrm{~nm}$ 에서 측정하였다. 컬럼은 C18 column $(4.6 \mathrm{~mm} \times 250 \mathrm{~mm}, 5 \mu \mathrm{m})$ 을 사용하여 $0.2 \%$ phosphoric acid $:$ acetonitrile $=65: 35(\mathrm{v} / \mathrm{v})$ 로 한 용액 을 이동상으로 하고 농도 변화를 주며 $1 \mathrm{~mL} / \mathrm{min}$ 의 유속으 로 주입하여 분석하였다. 표준물질은 비활성형의 경우 Sigma (USA)로부터 구입하여 표준물질 $10 \mathrm{mg}$ 을 $75 \%$ 에탄올 $50 \mathrm{~mL}$ 에 녹여 $200 \mathrm{ug} / \mathrm{mL}$ 농도로 한 다음 사용하였고, 활성형은 비활성형 표준물질 용액 $2 \mathrm{~mL}$ 를 $0.5 \mathrm{~mL} 0.05 \mathrm{~N} \mathrm{NaOH}$ 에 혼합한 후 실온에서 방치 한 후 표준용액으로 사용하였다.

Citrinin의 분석은 HPLC (Dionex ultimate3000)를 이용 하여 fluorescence detector를 이용하여 측정하였다. 컬럼은 C18 column $(4.6 \mathrm{~mm} \times 250 \mathrm{~mm}, 5 \mu \mathrm{m})$ 을 사용하여 $0.12 \%$ trifluoride acetic acid : acetonitrile $=60: 40(\mathrm{v} / \mathrm{v})$ 로 한 용액 을 이동상으로 하고 $1 \mathrm{~mL} / \mathrm{min}$ 의 유속으로 fluorescence detector를 이용하여 $\lambda \mathrm{ex}=335 \mathrm{~nm}, \lambda \mathrm{em}=502 \mathrm{~nm}$ 에서 측정 하였다. 표준물질은 Sigma (USA)로부터 구입하여 메탄올로 녹여 사용하였다.

\section{5. 액체 배양 후 균체와 배양액의 monacolin $\mathrm{K}$ 및 citrinin 분석}

액체배양 후 홍국균이 생산하는 성분을 분석하기 위하여 위 와 동일한 방법으로 액체배양 한 후 filter paper를 이용하여 균체와 배양액을 각각 별도로 분리하였다. 회수된 균체는 에탄올을 첨가하여 $25^{\circ} \mathrm{C}$ 에서 $180 \mathrm{rpm}$ 으로 1 시간 동안 교반 하며 추출한 다음 추출액에 포함된 monacolin과 citrinin의 함량을 HPLC로 분석하였다. 또한, 균체가 제거된 배양액은 별도로 모아 배양액에 포함된 monacolin과 citrinin의 함량을 $\mathrm{HPLC}$ 로 분석 하였다.

\section{3. 결과 및 고찰}

\section{1. 액체배지에서의 생장특성}

액체배지에서 $25^{\circ} \mathrm{C}$ 조건에서 Monascus spp. 균주를 PDYB, $\mathrm{PDB}, \mathrm{MEB}$ 배지에서 배양한 결과 대부분의 균주들이 $\mathrm{PDB}$ 나 MEB 배지에서보다 PDYB 배지에서 더 빠르게 자라는 것을 확인할 수 있었다 (Fig. 1). 또한, PDYB 배지에서의 배 양속도는 균주별로 정도의 차이가 있긴 하지만 대부분 $\mathrm{PDB}$ 나 MEB 배지에서의 배양속도보다 $30 \sim 50 \%$ 가량 증가한 것 을 알 수 있었다.

한편 이러한 결과는 각 균주의 기본 배양조건과는 상이한 결과라고 할 수 있다. 균주 제공기관에서 제시한 고체평 판배지를 볼 때 PDYA 배지는 6개 균주에만 추천되었고, $\mathrm{PDA}$ 가 10 개 균주, $\mathrm{MEA}$ 가 13 개 균주, 기타 $\mathrm{SDA}$ 나 $\mathrm{CMA}$ 배지가 6 개 균주에서 기본 배양 배지로 추천되었다. 그러 나, 액체배양 후 균사체의 량을 측정한 결과, 모든 균주에서 $\mathrm{PDYB}$ 가 가장 잘 자라는 배지로 나타났다. 이렇게 상이한 결과가 나타난 이유는 배지의 종류가 고체배지가 아닌 액체 배지로 바뀌었기 때문이라고도 볼 수 있으나, 그 배지의 형태 만 고체와 액체로 다를 뿐 성분이 동일한 것으로 보아, 균주 제공기관에서 제시하는 배지가 균주의 생장에 최적인 조건은 
아니라고 판단된다. 또한, 액체배지의 조성에 있어서 $\mathrm{PDYB}$ 에 훨씬 더 많은 영양소가 포함되어 있으므로 이러한 영향에 의한 것으로 보인다.

(a)
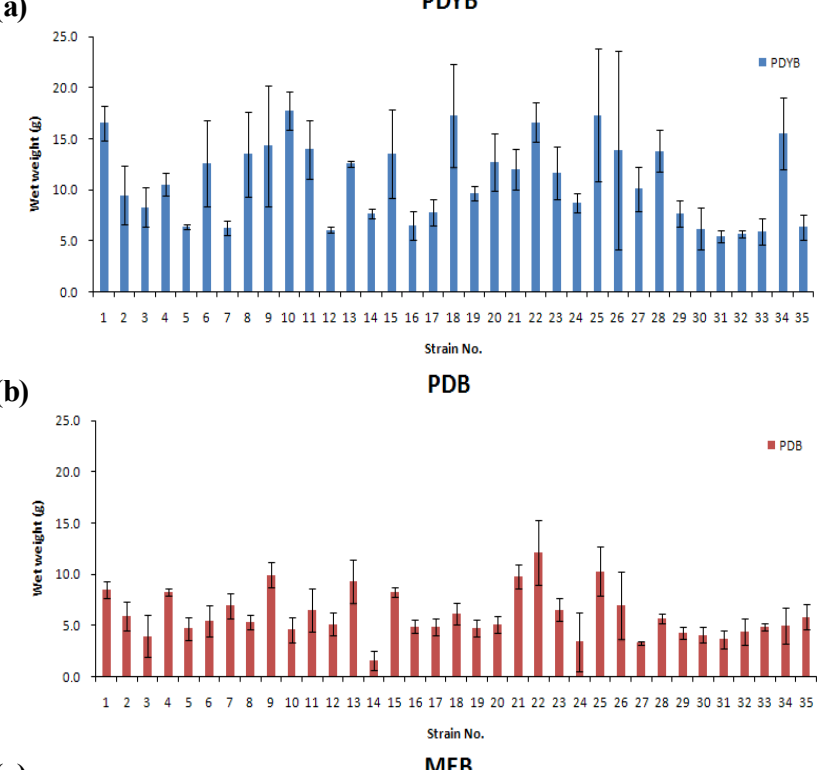

(c)

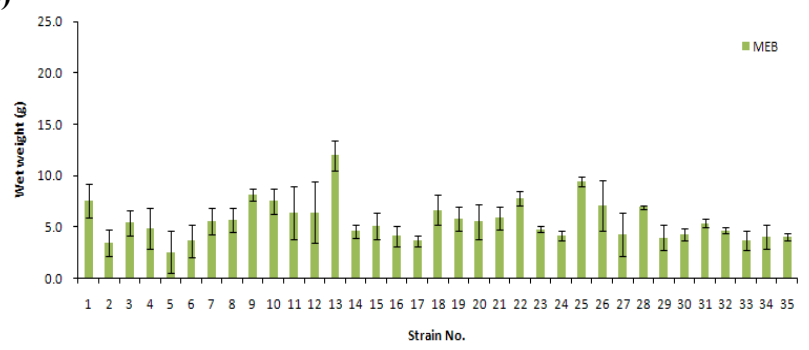

Fig. 1. Growth rates of Monascus strains in each medium. Wet cell weight was measured after incubation at $25^{\circ} \mathrm{C}, 180 \mathrm{rpm}$ for 7 days (a) PDYB (b) PDB (c) MEB.

균주별 액체배지에서의 배양속도를 비교해 본 결과 빨리 자라는 균주의 경우 PDYB배지에서 7일 후 대략 $16 \mathrm{~g}$ 의 균 체량을 얻을 수 있음을 알 수 있었다. 이와 비슷한 빠른 성장 속도를 가지는 균주로는 KCCM 60141, KCCM 60160, KCCM 60399, KCCM 60392, KCCM 60400, KACC 46226 를 포함한 6개 균주였으며, 그 외 $\mathrm{KCCM} 60462, \mathrm{KCCM}$ 60167, KCCM 60084, KCCM 11845, KCCM 11876, KCCM 60142, KCCM 60396, KCCM 60401, KCTC 6122 등이 비교적 빠르게 자람을 알 수 있었다. 또한, 이들 균주는 $\mathrm{PDYB}$ 외에 PDB, MEB 배지에서도 다른 균주에 비해 비교 적 빨리 자라는 경향을 보였다. 한편 MEB 배지에서는 특이 하게도 $\mathrm{KCCM} 11876$ 균주가 가장 빨리 자라는 특성을 보여 주었다 (Fig. 1(c)). 이 균주는 PDYB 배지에서도 비교적 잘 자라는 특성을 보였으나, 다른 균주에 비해 $\mathrm{MEB}$ 배지에 더 잘 적응된 것으로 보여진다.

\section{2. 배양액의 색}

액체배양 후 배양액의 색은 배지별, 균주별로 매우 다르게
나타나는 경향을 보였다 (Fig. 2). 대부분의 균주에서는 적색 혹은 오렌지색을 띄었으나, 몇 균주에서는 적색 계열의 색은 띄지 않고 노란색만 나타내었다. 또, 특정 균주의 경우엔 색 이 거의 변하지 않은 경우도 있었는데, 이러한 배양액의 색 은 균주의 배양 상태와도 밀접한 연관성이 있는 것으로 판단 되었다. 특히 노란색을 나타내거나 색의 변화가 거의 없는 경우는 대부분이 균주가 배지에 잘 현탁되지 않고 뭉쳐지는 형태로 배양될 때 나타났다 (Fig. 2(b)). 따라서, 균주의 액체 배양시 색을 진하게 나타내기 위해서는 균주의 현탁배양 조 건을 찾는 것이 중요할 것으로 판단되었다.

배지에 따라서도 액체 배양한 균주의 배양액의 색이 매우 다르게 나타났는데, PDYB 배지에서 진한 적색으로 변한 균 주는 KCCM 60141, KCCM 60461, KCCM 60167, KCCM 60160, KCCM 60394, KCTC 6122, KACC 46226 균주였 다(Fig. 2(a)). PDB 배지에서는 KCCM 11876, KCCM 60392 균주가 진한 적색을 나타내었다 (Fig. 2(c)(d)). 이러한 균주 들은 대부분이 생장속도가 빠른 균주에 해당하여 배양액의 색의 변화는 균주의 생장속도와도 많은 상관관계가 있는 것 으로 보인다. (a)

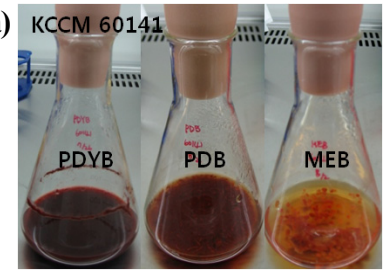

(c)

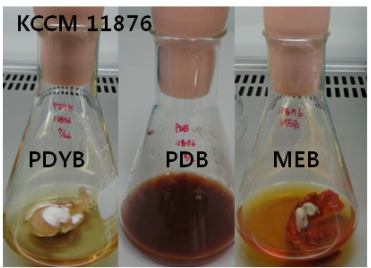

(e)

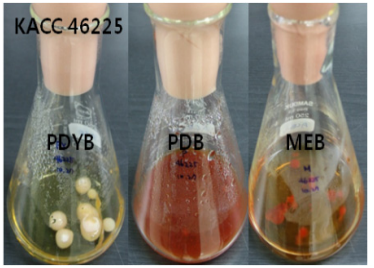

(b)

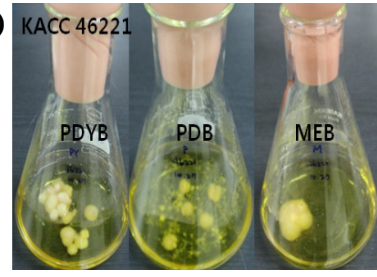

(d)

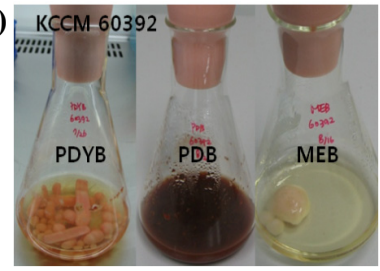

Fig. 2. Growth characteristics and color changes of Monascus strains in PDYB, PDB, and MEB media. (a) M. ruber KCCM 60141 (b) M. perpureus KACC 46221 (c) M. ruber KCCM 11876 (d) M. ruber KCCM 60392 (e) M. ruber KACC 46225.

\section{3. 색소성분}

각 균주를 액체배지에서 배양 한 후 색소의 함량을 spectrophotometer로 분석한 결과 적색 색소는 $\mathrm{KCCM} 60141$, KCCM 60167, KCCM 60160, KCCM 60394, KACC 46225, $\mathrm{KACC} 46226$ 균주의 배양액에서 높은 것을 알 수 있었 고 (Fig. 3(a)), 황색 색소는 KCCM 60141, KCCM 60167, KCCM 60160, KCCM 60392, KCTC 6122 KACC 46221, $\mathrm{KACC} 46225, \mathrm{KACC} 46226, \mathrm{KACC} 46319$ 균주의 배양액 
(a)

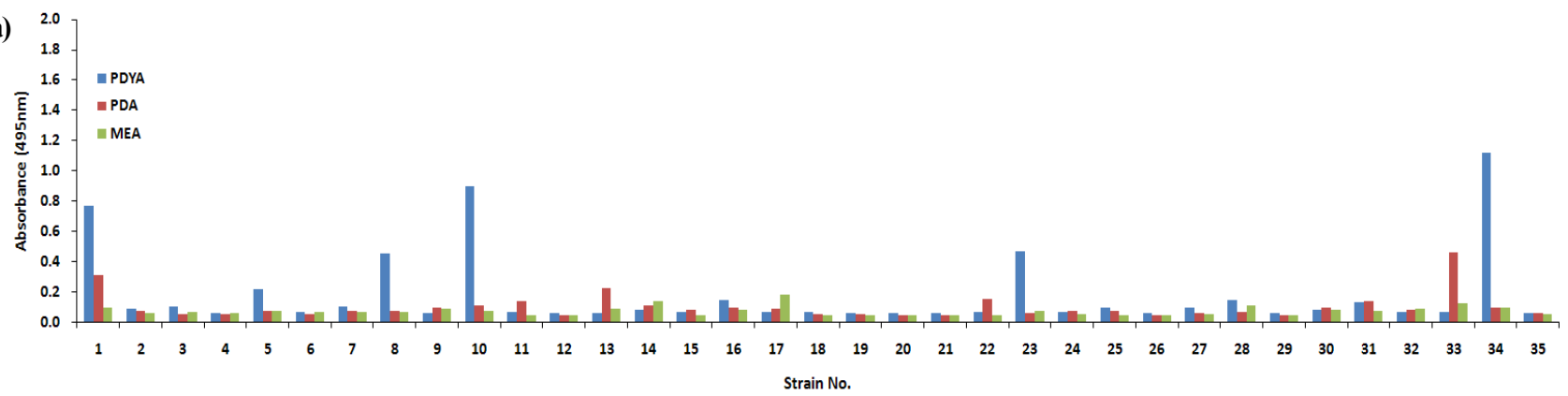

(b)

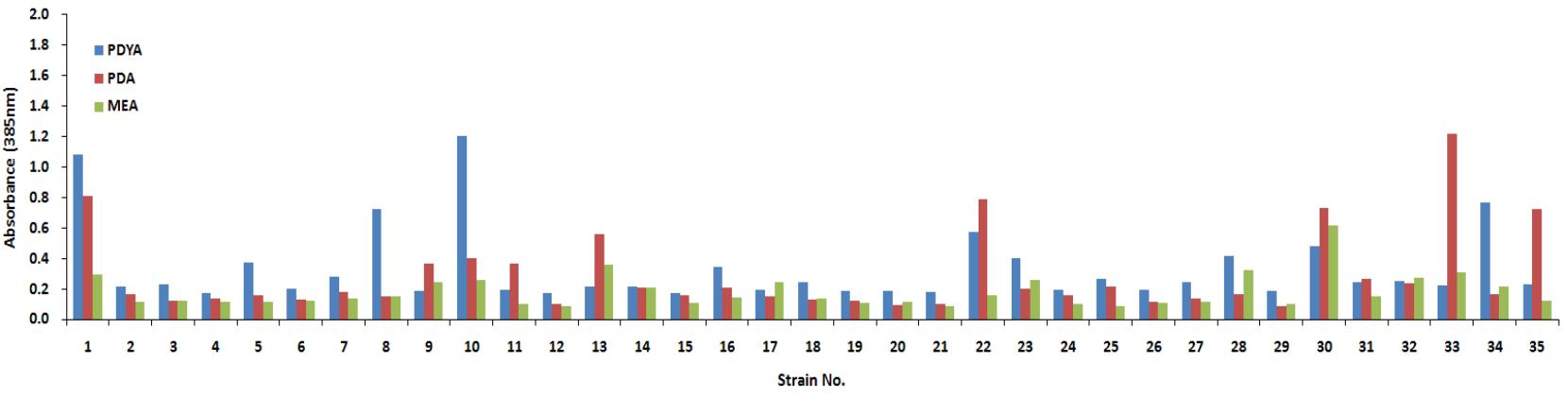

Fig. 3. Pigment production by Monascus strains. (a) Red pigment was measured as absorbance at $495 \mathrm{~nm}$ by spectrophotometer. (b) Yellow pigment was measured as absorbance at $385 \mathrm{~nm}$ by spectrophotometer.

에서 높게 나타났다 (Fig. 3(b)). 이 중 상당수의 균주가 적색 색소와 황색 색소에 중복되어 나타나는데 이러한 결과는 대부 분의 균주에서 적색 계열의 색소와 황색계열의 색소를 동시 에 생산한다는 것을 의미한다.

한편, $\mathrm{KCCM} 60392$ 균주와 KACC 46221 균주의 경우 적색 색소는 거의 생산하지 않는 대신 황색 색소만 생산하는 것으로 나타났는데, PDYB 배지보다 PDB 배지에서 황색 색소를 더 많이 생산하는 경향을 나타내었다. 특히 KACC 46221 균주의 경우에는 PDYB, PDB, MEB 세가지 배지에서 모두 육안으로 보기에도 매우 노란 색을 나타내고 있어 황색 계열의 색소 생산에 유용한 균주로 판단되었다 (Fig. 2(b)).

KACC 46225와 KACC 46319 균주는 PDYB 배지에서보 다 PDB 배지에서 매우 높은 색소 생산량을 나타내었는데, 이는 균사체의 생장 특성과 밀접한 관계가 있는 것으로 보인 다. 두 균주 모두 액체 배양 후의 균사체 량은 매우 낮은 것 으로 나타났지만, 색소 생산량이 높은 PDB 배지에서의 배양 은 균사체가 현탁된 상태였으며, 색소 생산량이 낮은 PDYB 나 MEB 배지에서는 균사체가 뭉친 상태로 배양이 일어났
다 (Fig. 2(e)). 이러한 결과로 볼 때 균주의 배양상태가 색소 생산에 많은 영향을 미치는 것으로 판단된다 [21].

한편 기기를 이용하여 측정한 색소생산량과 육안으로 적 색을 판별한 결과가 완전히 일치하지 않아 육안판별이 실제 균주의 색소 생산량과는 다름을 알 수 있었다. 그러나, 균주 별 배양결과 적색색소를 많이 생산하는 균주에서 황색색소 의 생산량도 전반적으로 높게 나타남으로 색소를 많이 내는 균주가 별도로 있음을 알 수 있었다.

\section{4. $\mathrm{pH}$ 변화}

각 균주를 액체배양하기 전 사용한 액체배지인 PDYB, PDB, $\mathrm{MEB}$ 의 $\mathrm{pH}$ 를 측정한 결과 각각 $5.1,5.2,4.8$ 로서 약산성을 띠고 있었다. 그리고 배양 후의 각 균주별 배양액의 $\mathrm{pH}$ 를 측정한 결과 대부분의 균주에서는 4.5 5.0 사이의 $\mathrm{pH}$ 를 나 타내어 배양 초기와 크게 다르지 않음을 알 수 있었다. 그러 나, KCCM 60141, KCCM 60167, KCCM 60160, KCCM 60394, KACC 46224 균주는 PDYB에서 배양할 때 $\mathrm{pH}$ 가 6.5 7.0 가까이 변하여 중성으로 바뀌는 것을 알 수 있었

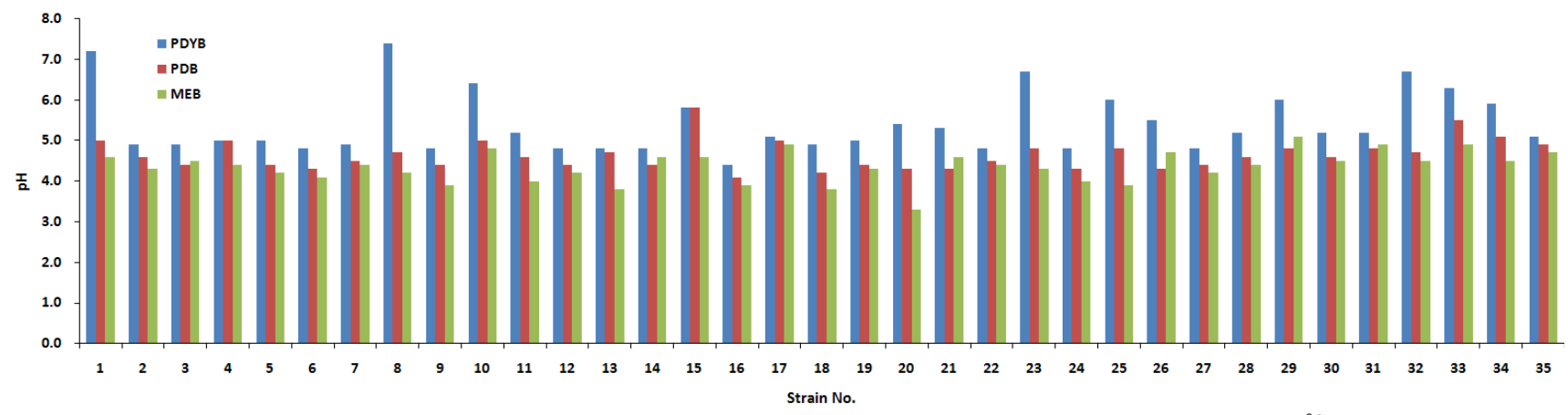

Fig. 4. Changes of $\mathrm{pH}$ in $\mathrm{PDYB}, \mathrm{PDB}$, and MEB midia. $\mathrm{pH}$ was measured after incubation of Monascus strains at $25^{\circ} \mathrm{C}, 180 \mathrm{rpm}$ for 7 days. 
다 (Fig. 4). 이러한 $\mathrm{pH}$ 의 변화는 균주가 성장하면서 일어나 는 여러 대사물질의 분비와 이차 대사산물의 생성과 연관된 것으로 판단된다.

이와 같은 결과를 바탕으로 비교해 볼 때 액체배지에서 색소 생산량이 높은 균주와 $\mathrm{pH}$ 의 변화가 큰 균주들이 대부 분 일치함을 알 수 있었고, 특히 적색 색소의 생산량이 높은 균주의 경우 $\mathrm{pH}$ 가 중성에 가깝게 높아 진 균주와 거의 일치 함을 알 수 있었다 [22]. 이를 통해 적색색소의 생산과 $\mathrm{pH}$ 의 변화가 밀접하다는 것을 알 수 있었고, 이것은 향후 색소 생 산균주의 선발에 새로운 균주 선발 방법으로 사용 가능할 것 으로 생각된다. 또한, $\mathrm{pH}$ 와 색소 생산이 연관되어 있다는 것 을 바탕으로 배양시의 $\mathrm{pH}$ 변화를 통해 이차 대사산물의 생산 을 조절할 수도 있을 것으로 판단된다 [23].

\subsection{Monacolin $K$ 및 citrinin 함량}

균체 생장이 빠르게 일어나는 PDYB 배지를 이용하여 각 균주를 액체배양 한 후 균체와 배양액에 있는 monacolin $\mathrm{K}$ 와 citrinin의 함량을 분석하였다. $\mathrm{KCCM} 60141, \mathrm{KCCM}$ 60167, KCCM 60160, KCCM 60394, KCTC 6122 균주에서 monacolin $\mathrm{K}$ 가 검출되었는데, 이들은 균체와 배양액 모두 에서 monacolin $\mathrm{K}$ 가 검출되었다 (Table 2).

또한, 균체와 배양액에 함유된 monacolin $\mathrm{K}$ 의 함량을 비 교해 보면, KCCM 60167, KCCM 60160, KCCM 60394, KCTC 6122 균주에서는 배양액보다 균체 내의 monacolin K 함량이 더 많이 있음을 알 수 있었고, KCCM 60141 균주에 서만 배양액의 monacolin $\mathrm{K}$ 함량이 더 높음을 알 수 있었 다. 이러한 결과로 볼 때 $\mathrm{KCCM} 61141$ 균주가 다른 균주보 다 이차대사산물을 배양액으로 더 잘 분비한다고 생각되었 다. 대부분의 균주에서 배양액보다 균체에서 훨씬 더 많은 monacolin $\mathrm{K}$ 가 검출되고 있는데, 이는 균체 내에 생산된 monacolin $\mathrm{K}$ 가 균체에서 외부로 쉽게 분비되지 않는 것을 의미한다. 그러나, 이러한 균주를 이용하여 홍국쌀을 제조할 경우에도 홍국 균사체 자체를 홍국쌀에서 이용하고 있으므로 홍국쌀을 제조하는데는 큰 어려움이 없을 것으로 판단된다.

한편, 각 균주의 monacolin $\mathrm{K}$ 생산량을 비교해 볼 때 $\mathrm{KCCM}$ 60160 균주가 상대적으로 가장 높은 생산량을 나타내었지만, 매우 낮은 수준임을 알 수 있다. 이는 배양조건이 이차 대사 산물의 생산보다 균주의 생장 자체에 맞추어져 있기 때문에 나타난 결과로 보이며, 배양조건이 변할 경우 생산량은 더 크게 증가할 것으로 판단된다 [24]. 이에 따라 액체배양조건 이 최적화 되지 않은 상황에서 monacolin $\mathrm{K}$ 가 검출된 균주 는 배양조건 최적화를 통한 공정 개발을 하면 홍국쌀을 제조 하는데 유용하게 사용될 수 있을 것으로 판단된다.

각 균주는 생산하는 이차대사산물의 종류에 따라 크게 3 그룹으로 분류할 수 있었는데, 유용성분인 monacolin $\mathrm{K}$ 생 산 그룹, 독소성분인 citrinin 생산 그룹, 어느 것도 생산하지 않는 그룹으로 분류할 수 있었다. 특이하게도 monacolin K 를 생산하는 균주는 citrinin을 전혀 생산하지 않았는데 이는 이차 대사산물이 적게 만들어지고 있을 경우에는, monacolin $\mathrm{K}$ 와 citrinin 둘 중 어느 한 방향으로만 대사물이 생산되기 때문으로 판단된다.
Table 2. Monacolin K and citrinin production by Monascus strains on PDYB medium

\begin{tabular}{|c|c|c|c|c|}
\hline \multirow[b]{2}{*}{ Strain } & \multicolumn{2}{|c|}{ Culture broth } & \multicolumn{2}{|c|}{ Mycelium } \\
\hline & $\begin{array}{c}\text { Active } \\
\text { monacolin } \mathrm{K} \\
\text { (ppm) }\end{array}$ & $\begin{array}{c}\text { Citrinin } \\
(\mathrm{ppm})\end{array}$ & $\begin{array}{c}\text { Active } \\
\text { monacolin K } \\
\text { (ppm) }\end{array}$ & $\begin{array}{c}\text { Citrinin } \\
(\mathrm{ppm})\end{array}$ \\
\hline M. ruber КССМ 60141 & 6.12 & ND & 3.06 & ND \\
\hline M. perpureus KCCM 11832 & ND & 4.63 & ND & 9.70 \\
\hline M. perpureus KCCM 12002 & ND & 2.8 & ND & 7.04 \\
\hline M. perpureus КССМ 60170 & ND & 0.02 & ND & 0.06 \\
\hline M. perpureus KCCM 60461 & ND & 0.83 & ND & 3.85 \\
\hline M. perpureus KCCM 60462 & ND & 0.94 & ND & 3.32 \\
\hline M. perpureus КCCM 60016 & ND & 1.46 & ND & 8.22 \\
\hline M. ruber KCCM 60167 & 0.07 & ND & 0.35 & ND \\
\hline M.pilosus КССМ 60084 & 0.01 & ND & 0.05 & ND \\
\hline M. pilosus КССМ 60160 & 11.72 & ND & 14.78 & ND \\
\hline M. ruber KCCM 11845 & ND & ND & ND & ND \\
\hline M. perpureus KCCM 11847 & ND & 0.02 & ND & 0.2 \\
\hline M. ruber KCCM 11876 & ND & ND & ND & ND \\
\hline M. perpureus KCCM 35473 & ND & 1.78 & ND & 8.65 \\
\hline M. ruber KCCM 60142 & ND & ND & ND & ND \\
\hline M. perpureus KCCM 60168 & ND & 1.40 & ND & 6.54 \\
\hline M. perpureus КССМ 60344 & ND & ND & ND & ND \\
\hline M. pilosus KCCM 60399 & ND & ND & ND & ND \\
\hline M. pilosus КССМ 60398 & ND & ND & ND & ND \\
\hline M. pilosus KCCM 60396 & ND & ND & ND & ND \\
\hline M. perpureus КCСM 60169 & ND & ND & ND & ND \\
\hline M. ruber KCCM 60392 & ND & ND & ND & ND \\
\hline M. ruber КССМ 60394 & 0.78 & ND & 3.61 & ND \\
\hline M. perpureus KCCM 60397 & ND & 0.07 & ND & 0.11 \\
\hline M. ruber KCCM 60400 & ND & ND & ND & ND \\
\hline M. ruber КССМ 60401 & ND & ND & ND & ND \\
\hline M. perpureus КСТC 6121 & ND & 2.99 & ND & 6.63 \\
\hline M. ruber КCTC 6122 & 0.29 & ND & 1.76 & ND \\
\hline M. pilosus KACC 46219 & ND & ND & ND & ND \\
\hline M. purpureus KACC 46221 & ND & 33.99 & ND & 5.52 \\
\hline M. purpureus KACC 46222 & ND & 4.91 & ND & 2.38 \\
\hline M. ruber KACC 46224 & ND & ND & ND & ND \\
\hline M. ruber KACC 46225 & ND & ND & ND & ND \\
\hline M. ruber KACC 46226 & ND & ND & ND & ND \\
\hline M. pilosus KACC 46319 & ND & ND & ND & ND \\
\hline
\end{tabular}

ND: not detected.

또한, 액체배양에서 monacolin $\mathrm{K}$ 를 생산하는 균주와 색 소 함량이 높았던 균주와의 연관성을 찾아보면 특이하게도 적색 색소가 많이 발현되었던 균주인 KCCM 60141, KCCM 60167, KCCM 60160, KCCM 60394, KCTC 6122 균주에 서 모두 monacolin $\mathrm{K}$ 가 검출되었다. 이러한 사실은 홍국 이 생성하는 적색색소와 monacolin $\mathrm{K}$ 의 생성이 연관성이 있음을 시사하며 [25], 생합성이 동일한 경로를 거침으로 써 발생하는 것으로 판단된다 [17]. 또한, 배양액의 $\mathrm{pH}$ 의 변 화가 컸던 균주들도 대부분 monacolin $\mathrm{K}$ 를 생산한 것으 로 나타났다. 따라서, 이러한 사실에 기초하여 monacolin $\mathrm{K}$ 를 생산하는 홍국 균주를 스크리닝 할 때 액체배지에서 의 배양액의 $\mathrm{pH}$ 변화가 크고, 적색 색소의 생산량이 높은 균주를 우선적으로 선정하는 방법을 활용할 수 있을 것으 로 판단된다. 


\section{4. 결론}

홍국쌀 제조에 사용되는 홍국균의 액체배지에서의 생장 및 색소생산과 monacolin $\mathrm{K}$ 생산에 관한 특성에 대하여 조사 하였다. 총 35 개의 균주를 수집하여 $\mathrm{PDYB}, \mathrm{PDB}, \mathrm{MEB} 3$ 개 의 액체배지에 접종한 후 $25^{\circ} \mathrm{C}$ 에서 7 일 동안 배양하였다. 대부분의 균주가 PDYB 배지에서 가장 빠른 성장을 보여주 었으며, 적색계열의 색소생산량이 높은 균주는 황색계열의 색소생산량도 높았다. 또한, 균주의 생장 속도과 색소 생산 량은 모두 균주의 현탁 배양상태에 영향을 받고 있는 것으 로 나타났다. 액체배지에서 monacolin $\mathrm{K}$ 를 생산하는 균주는 대부분 적색 색소 생산량이 높은 균주와 배양액의 $\mathrm{pH}$ 변화 가 큰 균주들과 일치하였다. 이들 균주는 균체와 배양액에서 모두 monacolin $\mathrm{K}$ 가 검출되었으며, 독소성분인 citrinin은 전혀 검출되지 않았다. 이러한 결과로부터 액체배지의 종류 와 배양상태에 따라 균주의 생장과 색소생산량이 달라진다 는 것을 알 수 있었으며, 액체배지에서 적색 색소 생산량이 높고 $\mathrm{pH}$ 변화가 큰 균주를 선발하면 monacolin $\mathrm{K}$ 생산 균주 를 좀 더 쉽게 스크리닝 할 수 있을 것으로 판단된다.

\section{감사}

본 논문은 농촌진흥청 공동연구사업 (과제번호: PJ90709003) 의 지원에 의한 연구결과의 일부로서 연구비 지원에 감사 드립니다.

\section{References}

1. Tieghem, van P. (1884) Monascus, genre nouveau de l'ordre des Ascomycetes. Bull. Soc. Bot. Fr. 31: 226-231.

2. Went, F. A. F. C. (1895) Monascus purpureus le champignon de l'ang-quac une nouvelle thelebolee. Ann. Sc. Nat. Bot. 8: 1-17.

3. Hawksworth, D. L. and J. I. Pitt (1983) A new taxonomy for Monascus species based on the cultural and microscopical characters. Aust. J. Bot. 31: 51-61.

4. Choi, C. S. and C. P. Jeon (2009) Red yeast rice industry and green growth. Food Ind. Nutr. 14: 25-32.

5. Akihisa, T., H. Tokuda, K. Yasukawa, M. Ukiya, A. Kiyota, N. Sakamoto, T. Suzuki, N. Tanabe, and H. Nishino (2005) Azaphilones, furanoisophthalides, and amino acids from the extracts of Monascus pilosus-fermented rice (red-mold rice) and their chemopreventive effects. J. Agric. Food Chem. 53: 562-565.

6. Endo, A. (1979) Monacolin-K, a new hypocholesterolemic agent produced by a Monascus species. J. Antibiot. 32: 852-854.

7. Manzoni, M. and M. Rollini (2002) Biosynthesis and biotechnological production of statins by filamentous fungi and application of these cholesterol-lowering drugs. Appl. Microbiol. Biotechnol. 58: 555-564.

8. Ho, B.-Y. and T.-M. Pan (2009) The Monascus metabolite monacolin $\mathrm{K}$ reduces tumor progression and metastasis of Lewis lung carcinoma cells. J. Agric. Food Chem. 57: 8258-8265.
9. Park, C. D., H. J. Hang, H. W. Lee, H. S. Kim, and T. S. Yu (2005) Antioxidant activity of Monascus pigment of Monascus purpureus P-57 mutant. Korean J. Microbiol. 41: 135-139.

10. Hsu, W.-H., B.-H. Lee, T.-H. Liao, Y.-W. Hsu, T.-M. Pan (2012) Monascus-fermented metabolite monascin suppresses inflammation via PPAR-c regulation and JNK inactivation in THP-1 monocytes. Food Chem. Toxicol. 50: 1178-1186.

11. Martinkova, L., P. Juzlova, and D. Vesely (1995) Biological activity of polyketide pigments produced by the fungus Monascus. J. Appl. Bacteriol. 79: 609-616.

12. Shikeo, M. (1990) Function and utilization of Monascus sp. Tech. J. Food Chem. Chem. 12: 42-45.

13. Su, N. W., Y. L. Lin, M. H. Lee, and C. Y. Ho (2005) Ankaflavin from Monascus fermented red rice exhibits selective cytotoxic effect and induces cell death on Hep G2 cells. J. Agric. Food Chem. 53: 1949-1954.

14. Martinkova, L., P. Patakova-Juzlova, V. Kren, Z. Kucerova, V. Havlicek, P. Olsovsky, O. Hovorka, B. Rihova, D. Vesely, D. Vesela, J. Ulrichova, and V. Prikrylova (1999) Biological activities of oligoketide pigments of Monascus purpureus. Food Addit. Contam. 16: 15-24.

15. Juzlova, P., L. Martinkova, and V. Kren (1996) Secondary metabolite of the fungus Monascus. J. Ind. Microbiol. 16: 163-170.

16. Vinci, V. A., T. D. Hoerner, A. D. Coffman, T. G. Schimmel, R. L. Dabora, A. C. Kirpekar, C. L. Ruby, and R. W. Stieber (1991) Mutants of lovastatin-hyperproducing Aspergillus terreus deficient in the production of sulochrin. J. Ind. Microbiol. 8: 113-120.

17. Hajjaj, H., P. J. Blanc, E. Groussac, G. Goma, J. L. Uribelarrea, and P. Loubiere (1999) Improvement of red pigment/citrinin production ratio as a function of environmental conditions by Monascus ruber. Biotechnol. Bioeng. 64: 497-501.

18. Kim, H. J., G. E. Ji, and I. Lee (2007) Natural occurring levels of citrinin and monacolin $\mathrm{K}$ in korean Monascus fermentation products. Food Sci. Biotechnol. 16: 142-145.

19. Kim, S. J., J. W. Rhim, S. G. Kang, and S. T. Jung (1997) Characteristics and stability of pigments produced by Monascus anka in a jar fermenter. J. Korean Soc. food Sci. Nutr. 26: 60-66.

20. KFDA (2010) Health Functional Food Code. Korea Food and Drug Adminstration, Seoul, Korea.

21. Babitha, S., C. R. Soccol, and A. Pandey (2007) Effect of stress on growth, pigment production and morphology of Monascus sp. in solid cultures. J. Basic Microbiol. 47: 118-26.

22. Lee, C.-L. and T.-M. Pan (2012) Development of Monascus fermentation technology for high hypolipidemic effect. Appl. Microbiol. Biotechnol. 94: 1449-1459.

23. Lee, C. L., H.-K. Hung, J.-J. Wang, and T.-M. PAN (2007) Improving the ratio of monacolin $\mathrm{K}$ to citrinin production of Monascus purpureus NTU 568 under Dioscorea medium through the mediation of $\mathrm{pH}$ value and ethanol addition. $J$. Agric. Food Chem. 55: 6493-6502.

24. Lee, S.-K., G.-T. Chun, and Y.-S. Jeong (2008) Production medium optimization for Monascus biomass containing high content of monacolin-K by using soybean flour substrates. Korean J. Biotechnol. Bioeng. 23: 463-469.

25. Youn, U. K., Y. H. Kim, and S. D. Kim (2003) Pigment and monacolin K content of Beni-koji fermented with soybean curd residue. Korean J. Food Preserv. 10: 360-364. 